\title{
Entrepreneurship Development Factors which have impact on profit of IT Entrepreneurship
}

\author{
Rajib Kumar Roy ${ }^{1}$, Dr. R. Duraipandian² \\ ${ }^{1} \mathrm{PhD}$. Scholar, School of Commerce \& Management, Garden City, University, Bangalore. \\ ${ }^{2}$ Professor \& Research Supervisor, School of Commerce \& Management, Garden City, University, Bangalore \\ Email: ${ }^{1}$ racehorseind@gmail.com, ${ }^{2}$ duraipandian.r@ gardencity.university
}

\begin{abstract}
The aim of this study is to find out the impact of Entrepreneurial Development factors towards the business growth for IT entrepreneurships in Bangalore. Sample is collected from 200 individuals associated with IT entrepreneurships of Bangalore. We have undertaken the 15 entrepreneurship development factors which effect local IT business. We have taken continuous business profit for 3 years as measurement of success factors for the business. During study it was identified that certain Entrepreneurial Development factors has significant impact on business success over other factors.
\end{abstract}

- Organizational Functional Competencies

- $\quad$ Entrepreneurial Competencies

- $\quad$ Competitive advantage of service and product offered

- $\quad$ Education of Entrepreneur

- $\quad$ Availability of suppliers

Keywords

Entrepreneurship Development factor, Business profit

Article Received: 02 November 2020, Revised: 24 November 2020, Accepted: 18 December 2020

\section{Introduction}

While studying the Entrepreneurship development factors, we identified that the entrepreneurships are influenced by various factors of entrepreneur's ability. These factors either leverage or exploit the condition of the ecosystem to establish the strong business model.

From the phase of development of an idea of a business, the entrepreneur's ability to analyze the ecosystem and individual credibility plays major role in shaping up entrepreneurship.

The background of entrepreneur, leadership skill, understanding the business, ability to manage business activities and exploiting the ecosystem plays vital role in execution of projects successfully and keep the business profitable.

The success of an entrepreneurship depends upon the dependent factor's impact on the business and the ability of entrepreneurship's sustainability with the social, economic and leadership ability of the entrepreneur.

During the study we have identified 15 development factors which has variant impact in entrepreneurships and related ecosystem.

\section{Literature review}

There are multiple factors which effect the entrepreneurship development factors and some of those contribute from environment (government, legal-fiscal) and some are individual characteristics of entrepreneurs. Shaping up the overall development model depending upon the factors contributing and/or creating perceived impact.

To deep dive and understand the micro external environment Boardman et al. (2004) and Johnson et al.
(2008) suggest using the five forces framework (completive rivals, new market entrants, suppliers, customers and product substitute) developed by Porter (1980). Porter's Five Forces framework help understanding a company's competitive environment. Five Forces analysis cis used to guide business strategy to increase competitive advantage Leff (1978) found that implementation of banking system that helps business to obtain formal fund promoting entrepreneurship. The effective usage of communication among companies in the eco system through cost effective information technology and strong management skill help promoting business.

To analyze the business external environment of an entrepreneurship, PESTLE analysis can be conducted. PESTLE analysis is a way to understand and evaluate the external environment of a business (Morden, 2007). In our business ecosystem, all organization is affected by external environment. Without understanding the external environment under which the new business is getting formed can't create right strategy. PESTLE analysis is a useful tool for understanding the "high level picture" of the environment in which the entrepreneur's new firm will be operating.

In the age of globalization, all business promote employee as a vital part of organization management system. This encourage Empowered employees to take better role and responsibilities and are willing to perform more efficient and effective manner compared to employee of legacy systembased organization culture (Agnete, Alsos G. and Ljunggren Elisabet 1998 "Babson- Kauffman entrepreneurship research conference" Vol 12: Babson Kauffman Institute)

In 1993 King and Levine found that financial system plays vital role in the entrepreneurial actions that affects in 
multiple ways (1) Business is analyzed through the RoI of business case and efficient financial system help choosing the most value-added projects after evaluating the factors of projects from the angle of finance (2) Effective financial process help in allocation of funds to ensure smooth execution of projects or business process (3) Mature finance system help investor to understand and map the risk associated with uncertain deliverable or related innovations

(4) Robust financial system engages current capabilities to develop customer centric solution in lesser cost. Good financial process accelerates productivity and growth. King suggests that effect government policies toward financial policies may have a strong effect on long term growth. Smallbone and Welter (2001) identified that our economic development is majorly contributed by encouraged entrepreneurs through value addition, job creation and innovations. The use the to help market reformation and develop the market priorities as a part of their business models. The government \& it's policies can help

Entrepreneurs to handle any market difficulties and create potential for long term.

Liu, Burridge, and Sinclair (2002) studied the factors effecting the growth of trade and economic market through FDI in china. They collected and analyzed quarterly data for china's local market 's overall import, export and identified the effect on growth through FDI. They also identified the china's open-door policy help local companies to export faster and import effectively through FDI.

In 2004, Alfaro et al, examines the relationship between Foreign Direct Investment, local financial market and local business growth. He identified the for some entrepreneur's FDI sector provide better return as FDI sees faster growth in business and stronger footprint in the business ecosystem. This also help in growing countries economy faster.

Carland and Carland (2004) researched overall impact of entrepreneurship on generic employment and economic development in USA. Entrepreneurships with $<20$ employees have much stronger impact on economy, growth and making a difference on job creation for the decade of 1990's. Also, they identified that small firms have more potential towards future stability and economic reforms and govt. overall policy for entrepreneurship changes the outlook of economic structure.

In 2005 Wennekers et al found a U-shaped relationship (The U-shaped curve usually refers to the nonlinear relationship between two variables, in particular, a dependent and an independent variable. Because many analytic methods assume an underlying linear relationship, systematic deviation from linearity can lead to bias in estimation.) between entrepreneurial activities and level of economic development. When countries move from developing to advance, they should create a balance between economic profit, encourage FDI and promote stronger entrepreneurial and management initiatives to better incentive patters for advance countries.

Naudé (2008) shows that entrepreneurial activities have vital role has important role on shaping up economy. The entrepreneurial activities bring major change on innovations from all walks of life and contributes the change for better and modern economy. Advance countries promote selfemployment, quick ramp up on job creation and create better dynamics in quality of the solution or products.
Methodology: The aim was to analyze the Entrepreneurship Development factors which has impact on It entrepreneurship's profitability (a measure for success) . Following the objective, the below hypothesis was made

Ho: There is no influence of Entrepreneurship Development factors on profit of IT entrepreneurship Ha: There is influence of Entrepreneurship Development factors on profit of IT entrepreneurship

During the research, confidence level of $95 \%$ is identified from population. It was identified that 200 should be the sample size for analysis. Data collected from senior stakeholder of companies from operation, management, founder groups.

We identified the factors which has influence on entrepreneurships are

- Education of the entrepreneur: Fundamental knowledge, institutional studies, trainings etc.

- Previous work experience: subject matter knowledge on the similar business, process, technology

- Location of the business: business establishment

- Reputation of the entrepreneur: face value of the entrepreneur in the field of business

- $\quad$ Technology used in company: the base of solution platform, the development environment or DNA of solution

- $\quad$ Efficient tax system: The finance system to confirm on time payment of all taxes to govt. bodies

- $\quad$ Financial stability: The stable finance/accounts process to fund all activities like rent, wages, tax, collection, purchases without any outstanding

- Govt. support: how much Govt support required for the SME establishment, connecting eco system, benefits

- Business network relation: The connection with network where the solution is needed customer base, supplier base, marketing etc.

- $\quad$ Brand value of entrepreneurship: the face value of the entrepreneurship and it's visibility in the business platform

- Organizational functional competences: functional like customer development, product development, marketing, finance, human resource etc. which are essential and play major role in making effective organization practices

- $\quad$ Competitive advantage of services/offered product: the value-added benefits (cost, better feature, ease to handle, customer support etc.) of offered product and services over other competitors

- Management Competences: situational leadership, people management, innovations, project management, deliveries, quality assurance which plays vital as cause for developing right product

- Entrepreneurial competences: understanding of business scope, scope of innovation, value added solution, risk taking ability of entrepreneur

- $\quad$ Availability of Suppliers: third party suppliers for the business-like people, technology, hardware, etc.

been identified to collect the data. Likert scale-based survey is conducted through telephonic and email communication. Data collected using MS Excel and analysis processed we used SPSS. 


\section{Research Methodology}

During the data collection we have taken data from 200 senior business stakeholder individuals of IT entrepreneurship companies. The position of the stakeholder's play major role in our analysis. We have chosen only senior stakeholder of the business as they have more visibility, understanding and control over formation of business, operation / execution. So, we have taken people from business, consulting, Human resource and operation, solution delivery, head of IT. cadre/profession

\begin{tabular}{|l|l|l|l|l|}
\hline & Frequency & Percent & Valid Percent & $\begin{array}{l}\text { Cumulative } \\
\text { Percent }\end{array}$ \\
\hline Business head & 17 & 8.5 & 8.5 & 8.5 \\
Consulting head & 8 & 4.0 & 4.0 & 12.5 \\
Hr head & 28 & 14.0 & 14.0 & 26.5 \\
Valid & 43 & 21.5 & 21.5 & 48.0 \\
Senior delivery manager & 36 & 18.0 & 18.0 & 66.0 \\
Chief Business manager & 49 & 24.5 & 24.5 & 90.5 \\
Global IT lead & 49 & 9.5 & 9.5 & 100.0 \\
Director & 19 & 100.0 & 100.0 & \\
Total & 200 & & & \\
\hline
\end{tabular}

Table: 1: Professional level of the participants

When we checked the overall qualification of the professionals which gave us a good level of confidence as higher and medium qualification has a good distribution.

Qualification:

\begin{tabular}{|c|c|c|c|c|c|}
\hline & & Frequency & Percent & Valid Percent & $\begin{array}{l}\text { Cumulative } \\
\text { Percent }\end{array}$ \\
\hline Valid & $\begin{array}{l}\text { graduate } \\
\text { pg } \\
\text { above pg } \\
\text { Total }\end{array}$ & $\begin{array}{l}103 \\
71 \\
26 \\
200\end{array}$ & $\begin{array}{l}51.5 \\
35.5 \\
13.0 \\
100.0\end{array}$ & $\begin{array}{l}51.5 \\
35.5 \\
13.0 \\
100.0\end{array}$ & $\begin{array}{l}51.5 \\
87.0 \\
100.0\end{array}$ \\
\hline
\end{tabular}

Table: 2: Qualification level of the participants

During the data collection, we have taken 15 Entrepreneurial Development factors which we have shown above and We have taken two dependent variables namely

DV: Business Profit for last 3 years

The dependent variables are tested against 14 parameters separately to identify if there is a significant relationship between them. The overall goal of the multiple regression is to validate if there are some factors which has more significant over others on companies' profit.

Ever traditional business, we consider the business profit as measurement of performance and core fundamental of a business health.

In our first analysis, we did the significance analysis of 15 entrepreneurial development factors on Business Profit (DV). $\mathrm{R}$-squared measures the proportion of the variation in our dependent variable (DV) by our independent variables for a linear regression model. Adjusted R-squared adjusts the statistic based on the number of independent variables in the model.

When we did regression analysis, we found the below result. In our second analysis, we did the significance analysis of 15 Development factors on Business profit (DV).
Model Summary

\begin{tabular}{|c|c|c|c|c|}
\hline Model & $\mathrm{R}$ & R Square & $\begin{array}{l}\text { Adjusted } \\
\text { Square }\end{array}$ & $\begin{array}{l}\text { RStd. Error of } \\
\text { the Estimate }\end{array}$ \\
\hline 1 & $.957^{\mathrm{a}}$ & .917 & .910 & .317 \\
\hline
\end{tabular}

Table: 3: Model summary

\begin{tabular}{|c|c|c|c|c|c|}
\hline \multicolumn{6}{|c|}{ ANOVA $^{a}$} \\
\hline \multicolumn{2}{|c|}{ Mode } & $\begin{array}{l}\text { Sum } \\
\text { Squares }\end{array}$ & of $\mathrm{df}$ & $\begin{array}{l}\text { Mean } \\
\text { Square }\end{array}$ & Sig. \\
\hline \multirow[t]{3}{*}{1} & $\begin{array}{l}\text { Regressi } \\
\text { on }\end{array}$ & 203.415 & 15 & 13.561 & $135.170 .000^{\mathrm{b}}$ \\
\hline & Residual & 118.460 & 184 & .100 & \\
\hline & Total & 221.875 & 199 & & \\
\hline
\end{tabular}

Table: 4: Analysis of variance of 15 Entrepreneurial Development factors

When we did regression analysis, we found the below result. Coefficients

\begin{tabular}{|c|c|c|c|c|c|}
\hline \multirow[t]{2}{*}{ Model } & \multicolumn{2}{|c|}{$\begin{array}{l}\text { Unstandardi } \\
\text { zed } \\
\text { Coefficients }\end{array}$} & \multirow{2}{*}{\begin{tabular}{|l|} 
Stand \\
ardize \\
$\mathrm{d}$ \\
Coeffi \\
cients \\
Beta
\end{tabular}} & \multirow{2}{*}{$t$} & \multirow[t]{2}{*}{ Sig. } \\
\hline & B & $\begin{array}{l}\text { Std. } \\
\text { Error }\end{array}$ & & & \\
\hline (Constant) & -.188 & .241 & & -.781 & .436 \\
\hline $\begin{array}{l}\text { 10Education of the } \\
\text { entrepreneur }\end{array}$ & .062 & .025 & .059 & 2.522 & .013 \\
\hline Previous work experience & .052 & .028 & .058 & 1.895 & .060 \\
\hline Location of the business & .006 & .032 & .006 & .196 & .845 \\
\hline $\begin{array}{l}\text { Repulation of the } \\
\text { entrepreneur }\end{array}$ & .026 & .035 & .020 & .762 & .447 \\
\hline $\begin{array}{l}\text { Technology used in } \\
\text { company }\end{array}$ & -.001 & .034 & -.001 & -.040 & .968 \\
\hline Efficient tax system & .029 & .026 & .029 & 1.089 & .278 \\
\hline Financial stability & -.028 & .025 & -.027 & -1.149 & .252 \\
\hline Government support & -.038 & .030 & -.042 & -1.274 & .204 \\
\hline $\begin{array}{l}\text { Business } \quad \text { Network } \\
\text { relations }\end{array}$ & .014 & .033 & .013 & .415 & .679 \\
\hline $\begin{array}{l}\text { Brand value } \\
\text { Entrepreneurship }\end{array}$ & .000 & .028 & .000 & .015 & .988 \\
\hline $\begin{array}{l}\text { Organizational } \\
\text { Functional competences }\end{array}$ & 1.069 & .036 & .980 & $\begin{array}{l}29.66 \\
5\end{array}$ & .000 \\
\hline $\begin{array}{l}\text { Competitive advantage of } \\
\text { services / offered product }\end{array}$ & -.093 & .036 & -.079 & -2.540 & .012 \\
\hline Management competences & -.043 & .037 & -.034 & -1.153 & .250 \\
\hline $\begin{array}{l}\text { Entrepreneurial } \\
\text { competences }\end{array}$ & -.094 & .035 & -.073 & -2.656 & .009 \\
\hline Availability of Suppliers & .089 & .036 & .071 & 2.449 & .015 \\
\hline
\end{tabular}

Table: 5: Coefficient of 15 Entrepreneurship development factors on business profit

In the above Anova and regression table the p-value is less than 0.05 for the bold values indicating that it is significant so we conclude that there is influence of Entrepreneurial Development factors on business profit over the past three years. 


\section{Result and discussion}

Initially we created two hypotheses

Ho: There is no influence of Entrepreneurship Development factors on profit of IT entrepreneurship Ha: There is influence of Entrepreneurship Development factors on profit of IT entrepreneurship

During our analysis for the first dependent variable (DV: Business profit grown for last 3 years), An ANOVA analysis was performed and the results are displayed in table

4. The sum of squares reflects the variances and the ratio of the regression sum to the total sum 203.415/ 221.875=.915 which is the $\mathrm{R}$ square as shown in the table. 3 model summaries.

In the Anova analysis, 203.415 is the proportion of the total scattering, which is explained by the regression model.

18.460 quantifies the proportion of variance that cannot be explained by the regression model. 221.875 is the total scattering.

Based on the sum of squares as an unstandardized measure for the variance, the variance is further measured by the Ftest. The F-test checks whether the predictors are suitable for predicting the criterion. The F-test is based on a decomposition of the variance of the criterion in a declared and undeclared part. For this model, the F-ratio is 135.170. This results in a p-value of 0.000 . This gives an overview whether the model can predict the business success significantly well. Since the p-value of $0.000<0.005$, the null hypothesis should be rejected. The null hypothesis Ho says, that There is no influence of Entrepreneurial Development factors on performance of IT entrepreneurship.

In addition to that, the multiple regression shows the impact of each single independent variable on the dependent variable. Furthermore, the analysis can show how the dependent variable changes if the independent variables change and therefore delivers a prognosis.

The analysis shows that the factors which has most significant impact towards business profit as they have

$<0.05 \mathrm{p}$-value with positive significance

1. Organizational Functional Competencies (0.000)

2. Entrepreneurial Competencies (0.009)

3 . Competitive advantage of service and product

offered (0.012)

4. Education of Entrepreneur (0.013)

5. Availability of suppliers (0.015)

\section{Conclusion}

Entrepreneurship is not only about starting a new business; it's developing a culture of offering a scope-based solution to the eco-system. In our finding, organizational competency plays major role in entrepreneurship success/performance which is related to the functional areas like customer development, solution development, marketing, finance process, human resource. No business can sustain without an efficient execution of these functional areas. Entrepreneurial competencies are related with the understanding of business scope, scope of innovation, value added solution, risk taking ability of entrepreneur. When the business is small these competencies play major role to shape up the business towards gain and growth of success. Competitive advantage of offered product and services in the business eco-system holds the key of customer acquisition and solution penetration. Education of entrepreneur is a fundamental knowledge base through which a start-up business evaluates the market, position to develop right solution. Availability of supplier also play major role where companies depend upon third party toward absorbing valueadded demands like software, hardware (machine/servers), people (contractual staff), other technology (salesforce, CRM, network solutions) which plays integral role on the process of development of solution.

\section{References}

\section{[1] ENTREPRENEURSHIP} DEVELOPMENT IN INDIA: ROLE OF ECONOMIC GROWTH, FOREIGN INVESTMENT AND FINANCIAL DEVELOPMENT Amit Research Scholar, Indian Institute of Forest Management, Bhopal

[2] Agosin, M. R., \& Machado, R. (2005). Foreign investment in developing countries: does it crowd in domestic investment?. Oxford Development Studies,33(2),

[3] Alfaro, L., Chanda, A., Kalemli-Ozcan, S., \& Sayek, S. (2004). FDI and economic growth: the role of local financial markets. Journal of international economics, 64(1),

[4] Carland, J., \& Carland, J. (2004). Economic development: Changing the policy to support entrepreneurship. Academy of Entrepreneurship Journal, 10(2),

[5] Gujarati, Damodar. 2003. Basic Econometrics. New York: McGraw Hill King, R. G., \& Levine, R. (1993). Finance, entrepreneurship and growth. Journal of monetary Economics, 32(3),

[6] Leff, N. H. (1978). Industrial organization and entrepreneurship in the developing countries: The economic groups. Economic development and cultural change,

[7] https://relivingmbadays.wordpress.com/20 12/12/26/factors-affectingentrepreneurshipdevelopment/\#: :text=Entrepreneurship\% 
20is\%20influenced $\% 20$ by $\% 20$ four,strong $\% 20$ and $\% 20$ consistent $\% 20$ entrepreneurial $\% 20$ growth.

[8] Liu, X., Burridge, P., \& Sinclair, P. J. (2002). Relationships between economic growth, foreign direct investment and trade: evidence from China. Applied Economics, 34(11),

[9] Ministry of Finance. (2013). The interministerial committee for boosting exports from the MSME sector. Retrieved from http://dgft.gov.in/exim/2000/imcEXPORT-sme.pdf on 10 July 2014.

[10] Naudé, W. (2008). Entrepreneurship in economic development (No. 2008/20). Research Paper, UNU-WIDER, United Nations University (UNU). Smallbone, D., \& Welter, F. (2001).

[11] The role of government in SME development in transition economies. International Small Business Journal,19(4), pp 63-77. AIMA Journal of Management \& Research, August 2014, Volume 8 Issue 3/4, ISSN 0974 - 497 Copy right $\subseteq 2014$ AJMR-AIMA

[12] Wennekers, S., Van Wennekers, A., Thurik, R., \& Reynolds, P. (2005). Nascent entrepreneurship and the level of economic development. Small business economics, 24(3),

[13] Davidsson,P., \& Honig, B. (2003). The role of social and human capital among nascent entrepreneurs. Journal of business venturing, 18(3),

[14] AIMA Journal of Management \& Research, August 2014, Volume 8 Issue 3/4, ISSN 0974 - 497 Copy right $@ 2014$ AJMR-

AIMAhttps://www.forentrepreneurs.com/ why-startups-fail/

https://discuss.analyticsvidhya.com/t/differ ence-between-r-square-and-adjusted-rsquare/264/3Why Startups Fail And What You Can Do To Beat The Odds Kindle Edition by George Meszaros

[15] All In Startup: Launching a New Idea When Everything Is on the Line Kindle Edition by Diana Kander Why Startups
Fail: And How Yours Can Succeed by David

Feinleibhttp://www.forentrepreneurs.com/ why-startups-fail/ 